Provided for non-commercial research and education use. Not for reproduction, distribution or commercial use.

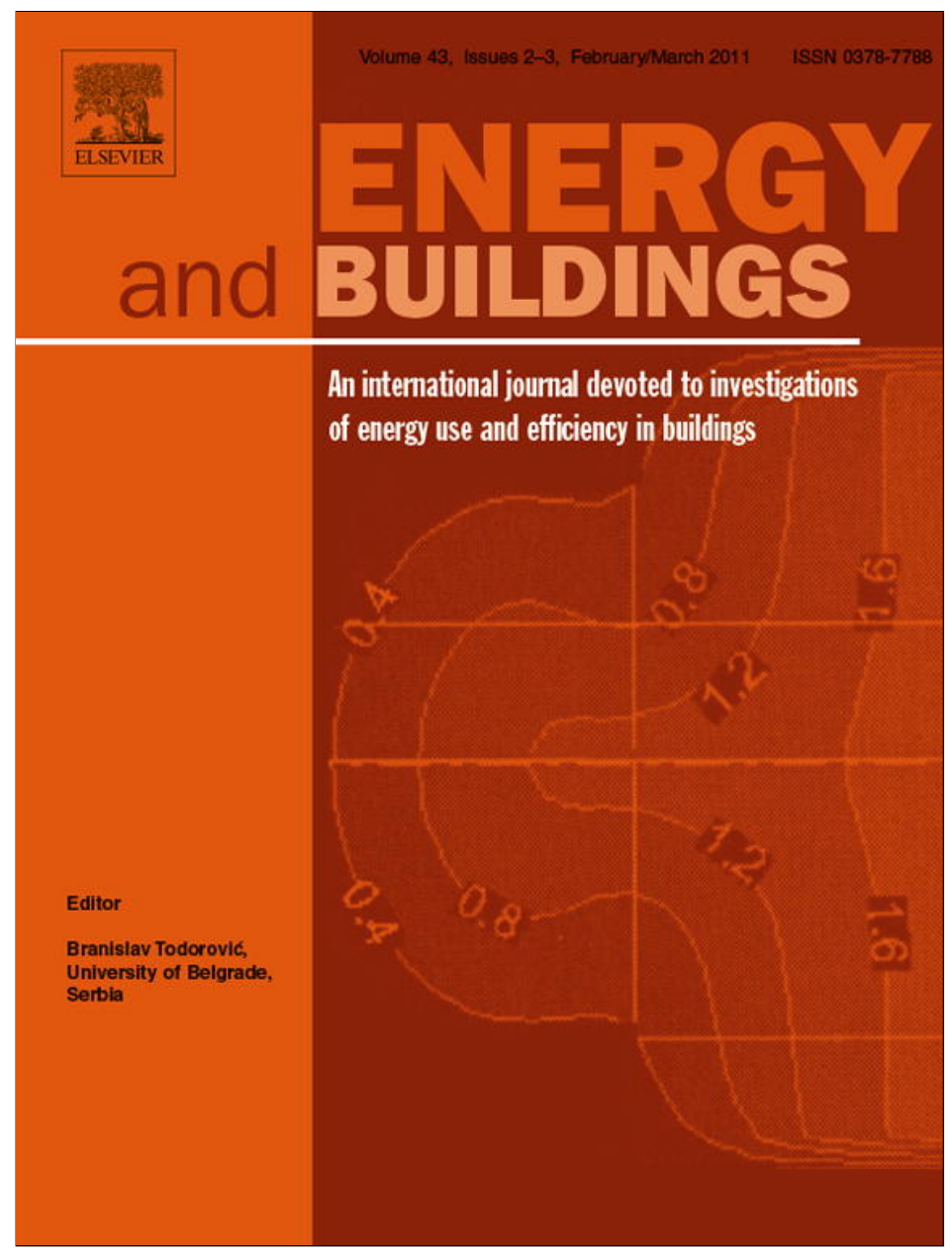

This article appeared in a journal published by Elsevier. The attached copy is furnished to the author for internal non-commercial research and education use, including for instruction at the authors institution and sharing with colleagues.

Other uses, including reproduction and distribution, or selling or licensing copies, or posting to personal, institutional or third party websites are prohibited.

In most cases authors are permitted to post their version of the article (e.g. in Word or Tex form) to their personal website or institutional repository. Authors requiring further information regarding Elsevier's archiving and manuscript policies are encouraged to visit:

http://www.elsevier.com/copyright 


\title{
Evaluation of adaptive thermal comfort models in moderate climates and their impact on energy use in office buildings
}

\author{
Maarten Sourbron*, Lieve Helsen \\ Katholieke Universiteit Leuven (K.U.Leuven), Department of Mechanical Engineering, Belgium
}

\section{A R T I C L E I N F O}

Article history:

Received 8 June 2010

Received in revised form 18 August 2010

Accepted 3 October 2010

Thermal comfort model

Office building

Energy use

Building simulation

\begin{abstract}
A B S T R A C T
Thermally Activated Building Systems (TABS) are regarded as top-cooling systems rather than full airconditioning systems. Therefore, adaptive thermal comfort models (ASHRAE55, ISSO74 or EN15251) are supposed to be applicable to TABS buildings, although the comfort model conditions are not necessarily satisfied. This paper investigates whether, for a moderate climate and with the heating and cooling set points chosen according to the adaptive models, the building's energy use reduces. After all, applying adaptive models, if appropriate, is thought to lower energy use because higher maximum operative zone temperatures $T_{o p, \max }$ are allowed, compared to the conventional ISO7730 model. For purpose of generality, a building with an ideal heating and cooling system is considered. Analysis of moderate climate weather data reveals a low energy reducing potential for the ASHRAE55 and ISSO74 model, because high reference outdoor temperatures hardly occur. EN15251 on the other hand, allows very high $T_{o p, \max }$ and will lower the cooling need.

A 2-zone building simulation demonstrates a higher cooling need for ASHRAE55 and ISSO74, compared to ISO7730. Because cooling is needed during the whole year, the lower winter $T_{o p \text {,max }}$ of these adaptive models causes these unexpected results. With real data of warmer years or varying gains, this conclusion holds.
\end{abstract}

(c) 2010 Elsevier B.V. All rights reserved.

\section{Introduction}

Thermal comfort being "that condition of mind which expresses satisfaction with the thermal environment" [1] is a definition much encountered in the literature. But what is often omitted is the affix "and is assessed by subjective evaluation", meaning that translating the conditions for achieving thermal comfort into universally applicable equations - a task which engineers very much like to perform - is a difficult, if not impossible task.

Several thermal comfort standards [1-4] provide information to the building designer on defining a good indoor climate. Subsequently, the choice of this thermal comfort model results in set points to be used in the HVAC installation. And therefore, this choice will influence the resulting energy use of the building meaning that the thermal comfort model chosen will be one of the factors determining the sustainability of the building.

For the design of buildings with Thermally Activated Building Systems (TABS), which are considered to be top-cooling systems rather than full air-conditioning systems and of which it is known that indoor temperatures vary during the course of the day [5,6], it is important to define suitable thermal comfort criteria. When choos-

\footnotetext{
* Corresponding author. Tel.: +32 163228 73; fax: +32 16322985 .

E-mail address: Maarten.Sourbron@mech.kuleuven.be (M. Sourbron).
}

ing between the basic thermal comfort models, with their fixed temperature limits, and the adaptive models, with their temperature limits varying with the outdoor temperature, it seems obvious to choose the latter for TABS buildings. However, the conditions for applying these adaptive thermal comfort models are not necessarily satisfied by TABS buildings. On the other hand, Pfafferott et al. [7] and Wagner et al. [8] conclude that the adaptive comfort criteria are applicable to both naturally ventilated as well as to, what they call, mixed-mode buildings. In their view, TABS buildings fall under this category.

Consequently, taking one step back to a more general level of building type, the question on how the choice of thermal comfort model influences the energy use, presents itself. Which HVAC set points result from the adaptive thermal comfort models of ASHRAE55 [1], ISSO74 [4] and EN15251 [2] for the moderate climate of Western and Central Europe, compared to the conventional PMV-PPD model given by ISO7730 [3]? And which impact has the choice of comfort model on the energy use? This article intends to respond to these questions.

\section{Thermal comfort theory}

\subsection{Basic thermal comfort theory}

The basic theory of thermal comfort, developed by Fanger and translated in the international standard ISO7730 [3], is based on the 
Table 1

Categories for global thermal environment from ISO EN 7730, Annex A (PPD: Predicted Percentage Dissatisfied; PMV: Predicted Mean Vote).

\begin{tabular}{lll}
\hline Category & \multicolumn{3}{l}{ Thermal state of the body as a whole } \\
\hline & $\operatorname{PPD}(\%)$ & PMV \\
\hline A & $\leq 6$ & $-0.2 \leq$ PMV $\leq+0.2$ \\
B & $\leq 10$ & $-0.5 \leq$ PMV $\leq+0.5$ \\
C & $\leq 15$ & $-0.5 \leq$ PMV $\leq+0.5$ \\
\hline
\end{tabular}

Table 2

Categories for local thermal environment from ISO EN 7730, Annex A (DR: draught rate, percentage of people bothered by draught; PD: percentage dissatisfied).

\begin{tabular}{lllll}
\hline Category & \multicolumn{2}{l}{ Local discomfort } & \\
\cline { 2 - 5 } & DR (\%) & PD (\%) caused by & & \\
\cline { 3 - 5 } & & $\begin{array}{l}\text { Vertical air } \\
\text { temperature difference }\end{array}$ & $\begin{array}{l}\text { Warm or } \\
\text { cold floor }\end{array}$ & $\begin{array}{l}\text { Radiant } \\
\text { asymmetry }\end{array}$ \\
\hline A & $\leq 10$ & $\leq 3$ & $\leq 10$ & $\leq 5$ \\
B & $\leq 20$ & $\leq 5$ & $\leq 10$ & $\leq 5$ \\
C & $\leq 30$ & $\leq 10$ & $\leq 15$ & $\leq 10$ \\
\hline
\end{tabular}

prediction of the number of dissatisfied people (PPD or Predicted Percentage of Dissatisfied). Literature on this theory is abundant, an excellent summary amongst others is given by Olesen and Parsons [9]. Annex A of this standard defines three categories of thermal environment - A, B and C - with prescribed limits for both global as well as local discomfort (Tables 1 and 2).

\subsection{Operative temperature}

Conventional, heat balance based, thermal comfort models, e.g. the ISO7730 model, are all based on environmental parameters from the direct surroundings of the occupants. Also, it is required to estimate the occupants' clothing insulation and metabolic rates. Input parameters needed to calculate thermal comfort are, amongst others, air temperature, mean radiant temperature, relative air velocity, water vapour partial pressure and local discomfort assessment. As it is difficult, certainly taking into consideration the accuracy levels of measuring instrumentation, to verify thermal conditions point by point, usually the equivalent operative temperature is used as defining parameter ([3], Annex A). The operative temperature is defined as:

$T_{o p}=$ the uniform temperature of an imaginary black enclosure in which an occupant would exchange the same amount of heat by radiation and convection as in the actual non-uniform environment [3].

or otherwise stated:

$T_{o p}=$ the average of the mean radiant and ambient air temperatures, weighted by their respective heat transfer coefficients [10].

$$
\begin{aligned}
T_{o p} & =A T_{a}+(1-A) T_{r} \\
& =\frac{h_{c} T_{a}+h_{r} T_{r}}{h_{c}+h_{r}}
\end{aligned}
$$

$A=\frac{h_{c}}{h_{c}+h_{r}}$

with:

- $T_{a}$ : indoor air temperature $\left({ }^{\circ} \mathrm{C}\right)$.

- $T_{r}$ : mean radiant temperature $\left({ }^{\circ} \mathrm{C}\right)$.

- $h_{c}$ : surface convection heat transfer coefficient of the clothed body $\left(\mathrm{W} / \mathrm{m}^{2} \mathrm{~K}\right)$.
Table 3

Optimal operative temperature and operative temperature band for thermal comfort in office environment [3].

\begin{tabular}{lll}
\hline Category & $\begin{array}{l}\text { Operative temperature }\left({ }^{\circ} \mathrm{C}\right) \\
\text { Winter }\end{array}$ & $\begin{array}{l}\text { Operative temperature }\left({ }^{\circ} \mathrm{C}\right) \\
\text { Summer }\end{array}$ \\
\hline A & $22.0 \pm 1.0^{\circ} \mathrm{C}$ & $24.5 \pm 1.0^{\circ} \mathrm{C}$ \\
B & $22.0 \pm 2.0^{\circ} \mathrm{C}$ & $24.5 \pm 1.5^{\circ} \mathrm{C}$ \\
C & $22.0 \pm 3.0^{\circ} \mathrm{C}$ & $24.5 \pm 2.5^{\circ} \mathrm{C}$ \\
\hline
\end{tabular}

- $h_{r}$ : surface radiation heat transfer coefficient of the clothed body $\left(\mathrm{W} / \mathrm{m}^{2} \mathrm{~K}\right)$.

At indoor air speeds below $0.2 \mathrm{~m} / \mathrm{s}, h_{c}=h_{r}$ and $A=0.5$ [1] which reduces Eq. (1) to:

$T_{o p}=\frac{T_{a}+T_{r}}{2}$

The mean radiant temperature is a hard to determine and position dependent quantity. It is often simplified by the area weighted mean of the surrounding surface temperatures, without taking view factors into account.

Nicol and Humphreys [11] indicate the operative temperature as a simple but well performing index, while more complex indices show a lower correlation with the comfort votes of the respondents.

Depending on the activity and the clothing level of the occupants, an optimal operative temperature exists, corresponding to $\mathrm{PMV}=0$. Each comfort category has the same optimal operative temperature, but has a different permissible range around this optimal point. This temperature is calculated assuming standard levels of activity, namely:

- a metabolic rate of 1.2 MET, corresponding to a body heat generation of $70 \mathrm{~W} / \mathrm{m}^{2}$ (sedentary activity-office, dwelling, school, laboratory);

- a clothing level of 0.5 CLO (short sleeved shirt, light trousers) during summer season and 1 CLO (shirt, trousers, jacket) during winter;

- a turbulence intensity of approximately $40 \%$ (mixing ventilation)

For these parameters, Table 3 summarizes the optimal operative temperature and the allowed temperature range for the different categories, as prescribed by the ISO7730 comfort model.

\subsection{Adaptation}

\subsubsection{Theory of adaptation}

The static thermal comfort model described in ISO7730 is often criticized as to recognize too little the outdoor climatic context and a person's ability to "fit" the indoor climate to its personal requests [12]. Therefore the static thermal comfort approach would contribute to an increased reliance on mechanical cooling. Since the energy use in office buildings is often dominated by the cooling requirements, the assumed lower energy use by using the adaptive thermal comfort models, is caused by their higher allowed operative temperatures.

Adaptive thermal comfort models assume that people adapt their thermal requirements because of three different mechanisms:

- Behavioural adaptation: clothing, activity, opening windows, operating fans, other time schedules, ...

- Physiological adaptation: acclimatization over a period of days or weeks to changing thermal stress factors

- Psychological adaptation: more relaxed indoor climate expectations makes occupants more tolerant to temperature swings 
de Dear and Brager summarized several extensive field studies [12] and concluded that in naturally ventilated buildings occupants seem capable of adapting to a broader range of conditions. They both accept higher indoor summer temperatures and lower indoor winter temperatures than predicted by ISO7730. Several attempts have been made to incorporate this adaptation into thermal comfort standards. They all relate the indoor operative temperature to a reference outdoor temperature. When using this outdoor temperature approach though, either adaptive or non-adaptive, care should be taken to assess local thermal discomfort when necessary [1]: local draft, cold floor, ....

\subsubsection{Adaptive thermal comfort models}

Olesen and Parsons [9] simply propose to use the category C criteria of ISO7730 for a non-air conditioned, 'free-running' building. However, the set points as summarized in Table 3 already implicitly take into account adaptive behaviour, namely changing clothing from summer $(0.5 \mathrm{clo})$ to winter period $(1 \mathrm{clo})$.

de Dear and Brager's proposal for adaptive comfort criteria [13] is incorporated into the most recent version of the ASHRAE standard 55 on thermal comfort [1]. It is limited to summer conditions only though (mean monthly outdoor temperature $>10^{\circ} \mathrm{C}$ ). Furthermore, ASHRAE limits its application to "spaces where the thermal conditions are controlled primarily through opening and closing windows by occupants" (naturally ventilated buildings). Unconditioned mechanical ventilation is allowed, but opening and closing windows must be the primary means of controlling thermal conditions. Occupants have to be allowed to freely adapt their clothing.

In the Dutch guideline ISSO74, described by van der Linden et al. [4], two building types ALPHA and BETA are defined as an alternative to the, in their opinion, confusing terms of 'Naturally ventilated' and 'Air-conditioned' buildings. An ALPHA building has an operable façade with at least one operable window or at least one temperature adjustment tool per two occupants and possibilities to adjust clothing to outdoor and indoor conditions. All other buildings are BETA buildings. Comfort limitations vary more for the ALPHA building than for the BETA building, although even the BETA building's thermal comfort criteria are linearly changing with the reference outdoor temperature. This is in contrast with the ISO7730 requirements. Compared with the de Dear and Brager criteria, they also define clear criteria for winter conditions.

The European standard EN15251 adopts the non-adaptive comfort model of ISO7730, and adds an adaptive model comparable to the de Dear and Brager's model. However, the recommended indoor operative temperature as a function of the reference outdoor temperature is shifted $1{ }^{\circ} \mathrm{C}$ higher. This results in a very high $T_{o p}$ for summer outdoor temperatures (Table 5). The fact whether this is still comfortable might be questioned (e.g. a running mean outdoor temperature of $21^{\circ} \mathrm{C}$ results in a $T_{o p, \max }$ of $28.7^{\circ} \mathrm{C}$ compared to $26.8^{\circ} \mathrm{C}$ for the ASHRAE55 model). However, this thermal comfort model is based on extensive measurement data analysis, described by Nicol and Humphreys [11], who also indicate the reasons for the shifted $T_{o p, \max }$-line. The conditions of building use are identical to the ASHRAE55 adaptive model. Annex G specifies deviations from the recommended limits stating that in $95 \%$ of the occupied space, a parameter can be outside the limits during $3 \%$ or $5 \%$ of the occupied hours. It is left to the designer to choose the time scale to which this is assessed.

Analogous to ISO7730, the ISSO74 model defines three classes of buildings, but with different levels of dissatisfied, compared to ISO7730 (Table 4). The ISSO74 model uses the same classification as de Dear and Brager [13] - class A with a PPD of $10 \%$ and class B with a PPD of $20 \%$ - but adds a class $C$ with a $65 \%$ level of acceptability (35\% dissatisfied). In this way the model can also deal with renovation projects of older buildings or temporary buildings with lower
Table 4

Building's thermal comfort classification comparison.

\begin{tabular}{lllll}
\hline Class & $\begin{array}{l}\text { ISO7730 } \\
\text { PPD (PMV) }\end{array}$ & $\begin{array}{l}\text { EN15251 adap } \\
\text { PPD (PMV) }\end{array}$ & $\begin{array}{l}\text { ASHRAE }_{\text {adap }} \\
\text { PPD (PMV) }\end{array}$ & $\begin{array}{l}\text { ISSO74 adap } \\
\text { PPD (PMV) }\end{array}$ \\
\hline A (I) & $6 \%( \pm 0.2)$ & $6 \%( \pm 0.2)$ & $10 \%( \pm 0.5)$ & $10 \%( \pm 0.5)$ \\
B (II) & $10 \%( \pm 0.5)$ & $10 \%( \pm 0.5)$ & $20 \%( \pm 0.85)$ & $20 \%( \pm 0.85)$ \\
C (III) & $15 \%( \pm 0.7)$ & $15 \%( \pm 0.7)$ & & $35 \%( \pm 1.76)$ \\
\hline
\end{tabular}

comfort criteria. An ISSO74 class A building must meet its comfort criteria during $90 \%$ of the time, the ISSO74 class B building must meet its requirements all the time and the same goes for the ISSO74 class C building. Tödtli et al. ([14], section 2.1.2) state correctly that this strict requirement should be subject to pre-design discussions between building designer and client. A limited violation of these limits, expressed in $\mathrm{Kh}$, can be tolerated.

In order to allow comparison of the different models in this article, the $10 \%$ PPD criteria are used in this article, being class B for ISO7730 and EN15251 and class A for ASHRAE55 and ISSO74.

\subsection{Thermal comfort boundaries in terms of outdoor temperature: overview}

The different guidelines relate the comfort temperature to an outdoor temperature $T_{\text {ref,out }}$. As already stated in Section 2.2 each category is no more than a certain temperature band around the optimal operative room temperature $T_{o p, o p t}$ in relation to the outdoor temperature. It should be noted that not every method uses the same definition for the outdoor temperature. Table 5 gives an overview. For the sake of completeness, the non-adaptive comfort model as defined by de Dear and Brager [12] and the non-adaptive model of the ISSO74 standard are also included in this table.

\subsection{Extrapolation of normative values}

In several cases the available standards do not give information about the full scale of outdoor reference temperatures appearing in a year. Therefore, some kind of extrapolation is provided.

The ISO7730 standard gives information on comfort temperatures in the 'heating' season and in the 'cooling' season, without specifying when these seasons start or stop, or how the comfort temperature is related to the outdoor temperature. In this work the EN15251 [9] approach is applied to the ISO7730 case:

- Heating season: outdoor running mean temperature $T_{r m}<10^{\circ} \mathrm{C}$ - Cooling season: outdoor running mean temperature $T_{r m}>15^{\circ} \mathrm{C}$

Annex 2 of EN15251 states that the upper limit should change from winter to summer at $T_{r m}=10^{\circ} \mathrm{C}$ and the lower limit at $T_{r m}=15^{\circ} \mathrm{C}$. To avoid this step change from winter to summer conditions, a linear interpolation is applied between $10^{\circ} \mathrm{C}$ and $15^{\circ} \mathrm{C}$. This assures a more gradual evolution of indoor temperatures more appropriate to the idea of adaptation between winter and summer conditions [15].

ASHRAE55 very clearly states that for the naturally ventilated buildings no specific guidance is included outside the given boundaries (mean monthly outdoor temperature $<10^{\circ} \mathrm{C}$ and $>33.5^{\circ} \mathrm{C}$ ). de Dear and Brager [13] admit that using this approach results in a step change in $T_{o p}$ if outside these limits the PMV model would be applied. In order to incorporate the adaptive ASHRAE55 model in the comparison, the following approach is used:

- Since mean monthly outdoor temperatures higher than $33.5^{\circ} \mathrm{C}$ do not occur for a typical moderate climate year, comfort limits do not need to be defined for these high temperatures. 
Table 5

Outdoor temperature definition and operative temperature band for thermal comfort in office environment according to different comfort models ( $T_{o p}:$ operative temp.; $T_{r m}$ : running mean outdoor temp.; $T_{e d-i}$ daily mean outdoor temp. of the $i$ th day before today; $t_{a, o u t}:$ mean monthly outdoor air temp.; $T_{e, r e f}$ : running mean outdoor temp., defined differently from $T_{r m} ; T_{\text {today }}$ : mean of maximum and minimum outdoor temp. of the specified day; $T_{\text {switch }}$ : see footnote 4 ).

\begin{tabular}{|c|c|c|c|}
\hline Thermal comfort model & Reference outdoor temp. $T_{\text {ref,out }}$ & Optimal operative temp. $T_{o p, o p t}$ & Allowed temp. range $T_{o p, \text { range }}{ }^{\mathrm{a}}$ \\
\hline ISO7730 & $\begin{array}{l}\text { Not used: } \\
T_{o p}=f(\text { winter }, \text { summer })\end{array}$ & $\begin{array}{l}\text { Winter: } 22.0^{\circ} \mathrm{C} \\
\text { Summer: } 24.5^{\circ} \mathrm{C}\end{array}$ & $\begin{array}{l}\text { A,winter: } 2^{\circ} \mathrm{C} \\
\text { B,winter: } 4^{\circ} \mathrm{C} \\
\text { C,winter: } 6^{\circ} \mathrm{C} \\
\text { A,summer: } 2^{\circ} \mathrm{C} \\
\text { B,summer: } 3^{\circ} \mathrm{C} \\
\text { C,summer: } 5^{\circ} \mathrm{C}\end{array}$ \\
\hline EN15251 $1_{\text {non-adap }}$ & $\begin{array}{l}T_{r m}=\frac{1}{3.8}\left(T_{e d-1}+0.8 T_{e d-2}+0.6 T_{e d-3}+0.5 T_{e d-4}\right. \\
\left.+0.4 T_{e d-5}+0.3 T_{e d-6}+0.2 T_{e d-7}\right)\end{array}$ & See ISO7730 & See ISO7730 \\
\hline \multirow[t]{2}{*}{ EN15251 adap } & see EN15251 non-adap & $\begin{array}{l}\text { Winter: } \\
\text { see ISO7730 }\end{array}$ & $\begin{array}{l}\text { A,B,C,winter: } \\
\text { see ISO7730 }\end{array}$ \\
\hline & & $\begin{array}{l}\text { Summer }{ }^{\mathrm{b}}: \\
T_{o p, o p t}=18.8+0.33 T_{r m}\end{array}$ & $\begin{array}{l}\text { A,summer: } 4^{\circ} \mathrm{C} \\
\text { B,summer: } 6^{\circ} \mathrm{C} \\
\text { C,summer: } 8^{\circ} \mathrm{C}\end{array}$ \\
\hline ASHRAE55 adap & $\begin{array}{l}t_{a, o u t}: \text { mean monthly } \\
\text { outdoor air temperature }\end{array}$ & $\begin{array}{l}T_{o p, o p t}=17.8+0.31 t_{a, o u t} \\
+10^{\circ} \mathrm{C} \leq t_{a, o u t} \leq 33.5^{\circ} \mathrm{C}\end{array}$ & $\begin{array}{l}\text { A: } 5^{\circ} \mathrm{C} \\
\text { B: } 7^{\circ} \mathrm{C}\end{array}$ \\
\hline $\begin{array}{l}\text { de Dear-Brager } \\
\text { for airco buildings }\end{array}$ & see ASHRAE55 adap & $\begin{array}{l}T_{o p, o p t}=22.4+0.05 t_{a, o u t}{ }^{\mathrm{c}} \\
-5^{\circ} \mathrm{C} \leq t_{a, o u t} \leq 33^{\circ} \mathrm{C}\end{array}$ & $\begin{array}{l}\text { A: } 5^{\circ} \mathrm{C} \\
\text { B: } 7^{\circ} \mathrm{C}\end{array}$ \\
\hline ISSO74 adap & $\begin{array}{l}T_{e, r e f}=\frac{1}{2.4}\left(T_{\text {today }}+0.8 T_{\text {today }-1}+0.4 T_{\text {today }-2}+0.2 T_{\text {today }-3}\right) \\
\left(-5^{\circ} \mathrm{C} \leq T_{e, r e f} \leq 30^{\circ} \mathrm{C}\right)\end{array}$ & $\begin{array}{l}T_{e, \text { ref }}<T_{\text {switch }}{ }^{\mathrm{d}}: \\
T_{\text {op }, \text { opt }}=21.45+0.11 T_{e, \text { ref }} \\
T_{e, \text { ref }}>T_{\text {switch }}: \\
T_{\text {op opt }}=17.8+0.31 T_{e, \text { ref }}\end{array}$ & $\begin{array}{l}T_{e, \text { ref }}<T_{\text {switch }} \\
\text { see ISSO74 } \\
T_{e, \text { non-adap }}>T_{\text {switch }} \\
T_{o p, \min }: \text { see ISSO } 74_{\text {non-adap }} \\
\text { A, } T_{o p, \max }:+2.5^{\circ} \mathrm{C} \\
\text { B, } T_{o p, \max }:+3.5^{\circ} \mathrm{C} \\
\mathrm{C}, T_{o p, \max }:+4.2^{\circ} \mathrm{C}\end{array}$ \\
\hline ISSO74 non-adap & see ISSO74 adap & $T_{o p, o p t}=21.45+0.11 T_{e, r e f}$ & $\begin{array}{l}\text { A: } 2.5^{\circ} \mathrm{C} \\
\text { B: } 4^{\circ} \mathrm{C} \\
\mathrm{C}: 5^{\circ} \mathrm{C}\end{array}$ \\
\hline
\end{tabular}

a Class A, B and C is not defined equally in each method, see Table 4.

b Change of winter to summer conditions in EN15251 adap: the upper limit changes for $T_{r m}>10^{\circ} \mathrm{C}$, the lower limit changes for $T_{r m}>15^{\circ} \mathrm{C}$

c Originally, de Dear and Brager formulated this equation [22] as a function of the outdoor effective temperature, where the effective temperature is the operative temperature of an enclosure at 50\% relative humidity which would cause the same sensible plus latent heat exchange from a person as would the actual environment. This was found to be a too impractical expression. For naturally ventilated buildings, it was reformulated in terms of $t_{a, \text { out }}[1,13]$. The same reformulation was used here for the de Dear-Brager's airconditioned buildings equation.

${ }^{\mathrm{d}} T_{\text {switch }}$ in the ATL method depends on the thermal comfort class, Class A: $T_{\text {switch }}=12^{\circ} \mathrm{C}$; Class B: $T_{\text {switch }}=11^{\circ} \mathrm{C} ;$ Class $\mathrm{C}: T_{\text {switch }}=10^{\circ} \mathrm{C}$.

- For temperatures lower than $10^{\circ} \mathrm{C}$, it is assumed that the comfort range remains constant for the lower temperatures: $18.4^{\circ} \mathrm{C} \leq T_{o p, o p t} \leq 23.4^{\circ} \mathrm{C}$ for the $90 \%$ buildings.

As a result, for these low outdoor temperatures, $T_{o p, \max }$ is $0.6^{\circ} \mathrm{C}$ lower than for the class B buildings of ISO7730. $T_{o p, \min }$ is considerably lower though. However, it should be clearly stated that, by strict definition, this adaptive model can not be applied to buildings in moderate climates (see also Section 3.2). Although the adaptive ASHRAE55 model will be used in the comparison with other models, this fact is kept in mind when analysing the results.

Fig. 1 gives an overview of the operative temperature ranges for the four thermal comfort models. The boxed areas indicate the extrapolated values compared to the definition in the respective standards.

\section{Thermal comfort limits for a moderate climate}

\subsection{Yearly comfort band}

With the different limits for thermal comfort, it is possible to produce an annual view of the thermal comfort limits based on a typical meteorological year (TMY), in this case for Maastricht, located in the south of the Netherlands. This site is chosen because of the availability of real weather data from the Royal Dutch Meteorological Institute (KNMI) [16]. With these data the TMY results are compared to results for warmer years during the last decade further on in this article.

Fig. 2 relates the comfort limits of Table 5 to the outdoor temperature data of Maastricht and shows that in summer time, compared to $T_{o p, \max }$ as prescribed by ISO7730, $T_{o p, \max }$ as determined by ASHRAE55 is almost never higher and $T_{o p, \max }$ as determined by ISSO74 is only at some points higher. Only the maximum operative temperatures as prescribed by EN15251 are never lower than ISO7730. Additionally, the maximum operative temperatures in wintertime are lower for the ASHRAE55 and the ISSO74 model. Taking in mind that the upper and lower comfort limits are the set points of respectively the cooling and heating system, based on to Fig. 2, it is not straightforward that, for a moderate climate, the energy use for cooling will be lower for the adaptive comfort models. Whether or not this statement holds, is dependant on the properties and use of the building in question.

\subsection{Quantified benefit of the adaptive comfort models}

With respect to the weather data, the hypothesis formulated in the previous section can be quantified. For the adaptive thermal comfort models, based on the data of Fig. 2, the number of Degree Days exceeding the ISO7730 $T_{o p, \max }$ value is an indicator for the potential energy savings attributed to the cooling system of the building.

Consequently, if a certain climate shows little or no 'ISO7730exceeding Degree Days', using the corresponding adaptive comfort 


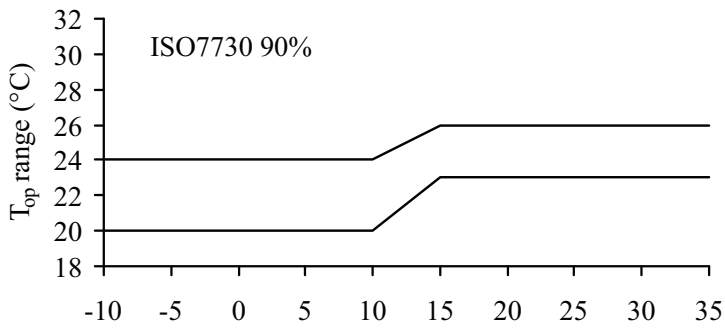

ISO7730 Reference outdoor temperature $\mathrm{T}_{\text {ref,out }}\left({ }^{\circ} \mathrm{C}\right)$

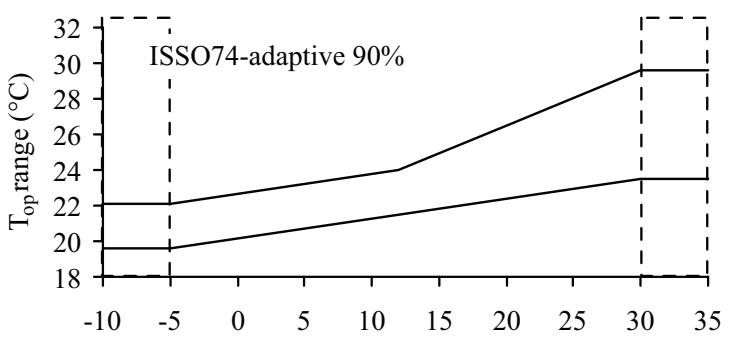

ISSO74 Reference outdoor temperature $\mathrm{T}_{\mathrm{e}, \mathrm{ref}}\left({ }^{\circ} \mathrm{C}\right)$

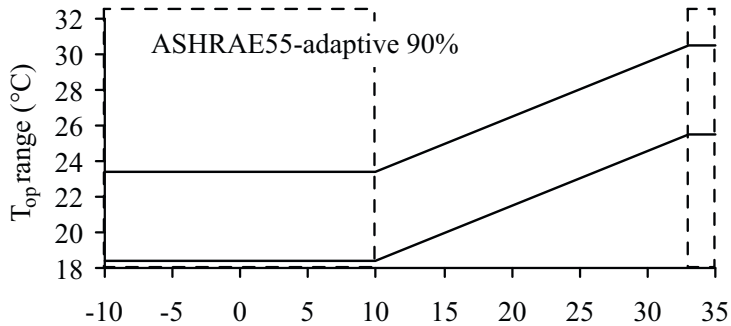

ASHRAE55 Reference outdoor temperature $\mathrm{t}_{\mathrm{a}, \text { out }}\left({ }^{\circ} \mathrm{C}\right)$

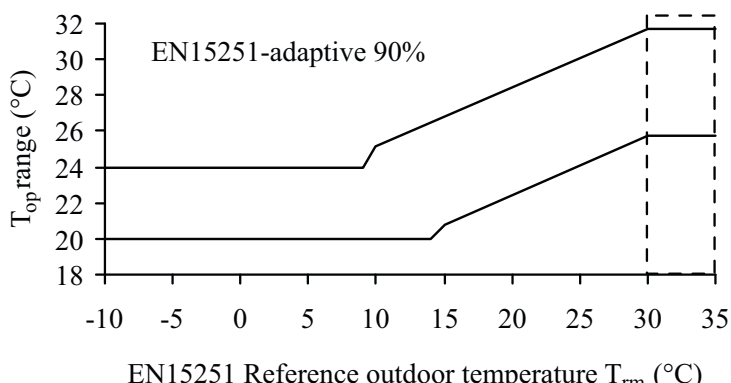

EN15251 Reference outdoor temperature $\mathrm{T}_{\mathrm{rm}}\left({ }^{\circ} \mathrm{C}\right)$

Fig. 1. Operative temperature range as a function of the reference outdoor temperature, according to the different thermal comfort models (boxed areas indicate the extrapolated values).

model will hardly allow higher operative temperatures than the ISO7730 model would do. On the contrary, with the lower winter set points for cooling for the ASHRAE55 and the ISSO74 model, a building with a cooling need in winter and mid season will be cooled to lower operative temperatures than with the ISO7730 model.

For the Maastricht TMY, this is quantified in Fig. 3(a). Compared to the ISO7730 $T_{\text {op, max }}$ value, the ASHRAE55 model has 1.4 Kday and the ISSO74 model has 10.1 Kday for the Maastricht TMY. The adaptive EN15251 model has a higher operative temperature starting from a reference outdoor temperature of $10^{\circ} \mathrm{C}$, resulting in a high number of Degree Days: 199.0 Kday. As a reference value, a whole year round $1{ }^{\circ} \mathrm{C}$ higher $T_{o p \text {,max }}$-value would give $365 \mathrm{Kday}$.

These values show that the benefit of the ASHRAE55 and the ISSO74 adaptive model - allowing higher summer indoor temperatures - is very limited if applied to a moderate climate. This was already indicated by van Hoof and Hensen [15] for the ISSO74 model. Moreover, because of the lower maximum operative winter and mid-season temperatures for ASHRAE55 and ISSO74 compared to ISO7730, the required cooling energy during these seasons might

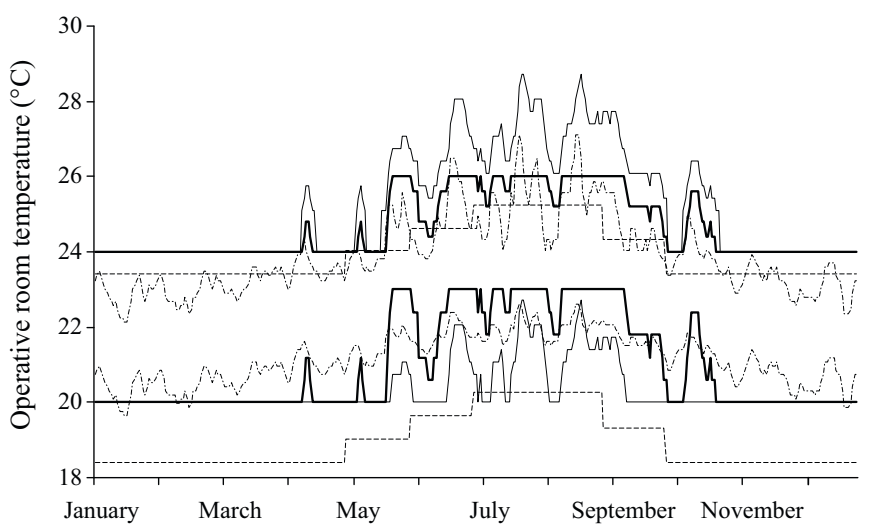

Fig. 2. Comfortable operative temperature range as a function of the corresponding reference outdoor temperature for the reference year of Maastricht, the Netherlands ('90\% satisfied' thermal comfort models; ISO7730: thick line; ASHRAE55: dashed line; ISSO74: dash-dotted line; EN15251: solid line).
Table 6

Mean outside temperature and global solar radiation on horizontal for Maastricht TMY and the years 2001-2008.

\begin{tabular}{lll}
\hline Year & $T_{\text {mean, outdoor }}\left({ }^{\circ} \mathrm{C}\right)$ & $I_{\text {global,horizontal }}\left(\mathrm{kWh} / \mathrm{m}^{2}\right)$ \\
\hline TMY & 9.5 & 1017 \\
2001 & 10.6 & 1033 \\
2002 & 11.1 & 1020 \\
2003 & 11.0 & 1176 \\
2004 & 10.4 & 1046 \\
2005 & 10.8 & 1064 \\
2006 & 11.2 & 1036 \\
2007 & 11.2 & 1012 \\
2008 & 10.5 & 1024
\end{tabular}

be higher if a cooling load is existing. Using EN15251, with a maximum operative temperature never being lower than ISO7730, a building will evidently end up with a lower required cooling energy.

\subsection{Real weather data analysis for Maastricht}

The last decade has had several years with substantially higher outdoor temperatures than the typical meteorological year. Consequently, the analysis of buildings with real weather data can deviate substantially from the TMY data. Table 6 shows the higher outdoor temperatures and demonstrates also that this does not automatically correspond to a higher solar radiation level. Data are taken from KNMI [16].

The year 2003 has a high mean temperature and a high amount of solar radiation. Therefore, this year will be used to compare the comfort model results with the TMY. Fig. 3(b) shows the 2003 results equivalent to Fig. 3(a) and Table 7 shows the difference between the TMY and the real weather data of 2003. From these

Table 7

Comparison of Maastricht TMY and the year 2003 'ISO7730-Exceeding' Degree Days (Kday).

\begin{tabular}{|c|c|c|c|c|c|}
\hline \multicolumn{2}{|c|}{ ASHRAE55 } & \multicolumn{2}{|c|}{ ISSO74 } & \multicolumn{2}{|c|}{ EN15251 } \\
\hline TMY & 2003 & TMY & 2003 & TMY & 2003 \\
\hline 1.4 & 28.2 & 10.1 & 45.8 & 199.0 & 310.9 \\
\hline
\end{tabular}




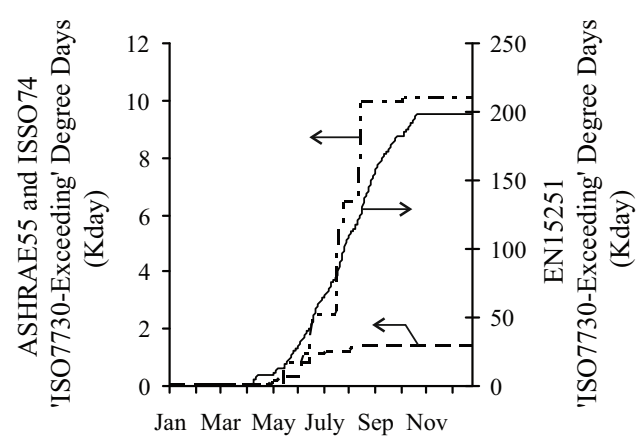

(a) Maastricht TMY

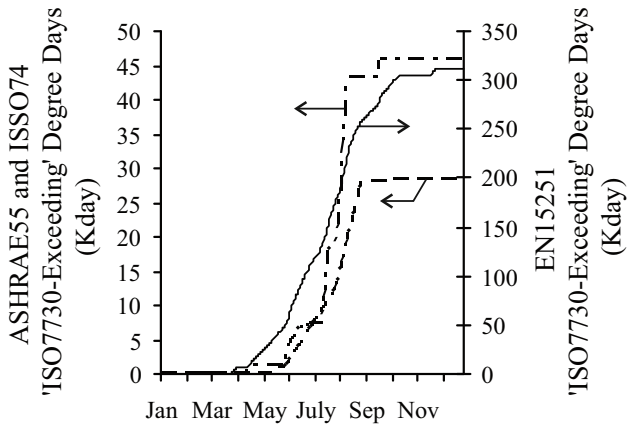

(b) Maastricht year 2003

Fig. 3. Adaptive thermal comfort models Degree Days exceeding the ISO7730 $T_{o p, \max }$ value for the Maastricht TMY (a) and for the Maastricht year 2003 (b) (ASHRAE55: dashed line; ISSO74: dash-dotted line; EN15251: solid line).

Table 8

$T_{o p, \min }$ and $T_{o p, \max }$ for Maastricht TMY and the year 2003.

\begin{tabular}{|c|c|c|c|c|c|}
\hline \multicolumn{3}{|l|}{$T_{o p, \min }$} & \multicolumn{3}{|l|}{$T_{o p, \max }$} \\
\hline Range & TMY & 2003 & Range & TMY & 2003 \\
\hline$<20^{\circ} \mathrm{C}$ & 209 & 185 & $<24^{\circ} \mathrm{C}$ & 209 & 185 \\
\hline $20.5^{\circ} \mathrm{C}$ & 0 & 0 & $24.5^{\circ} \mathrm{C}$ & 14 & 10 \\
\hline $21^{\circ} \mathrm{C}$ & 14 & 10 & $25^{\circ} \mathrm{C}$ & 15 & 18 \\
\hline $21.5^{\circ} \mathrm{C}$ & 15 & 18 & $25.5^{\circ} \mathrm{C}$ & 25 & 21 \\
\hline $22^{\circ} \mathrm{C}$ & 25 & 21 & $26^{\circ} \mathrm{C}$ & 102 & 131 \\
\hline $22.5^{\circ} \mathrm{C}$ & 22 & 21 & & & \\
\hline $23^{\circ} \mathrm{C}$ & 80 & 110 & & & \\
\hline
\end{tabular}

weather data, it can be concluded that the HVAC set points will deviate substantially, as can be seen from Table 8 .

\subsection{Weather data evaluation based on allowed operative temperatures}

While in Section 3.2 the weather data were related to the different comfort models by the $T_{o p, \max }$ difference between the non-adaptive and adaptive models, in this section, the number of days a minimum and maximum operative temperature occurs, is evaluated.

Fig. 4 presents the number of days that the minimal and maximal operative room temperature is equal or lower than the indicated abscissa temperature, according to the different comfort models. A steep curve indicates a requested operative room temperature that does not change much during the whole year. In other words, a steep curve relates to a method that is little adaptive to the out-

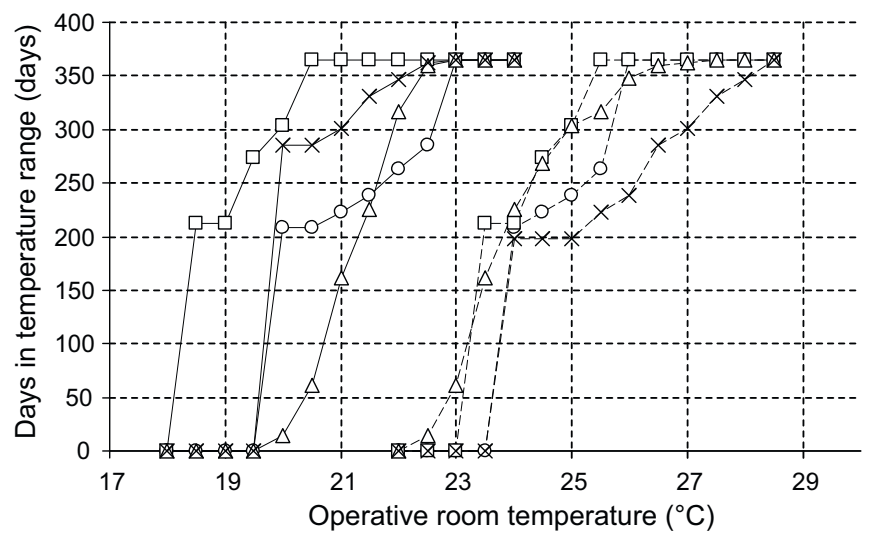

Fig. 4. Number of days the allowed lower (full line) and upper (dashed line) operative temperature is equal or smaller than the abscissa temperature, according to the different thermal comfort models (circle: ISO773; square: ASHRAE55; triangle: ISSO74; cross: EN15251). side temperature, a gradually increasing curve to a highly adaptive method. A building will have a low energy use for heating, the more the thermal comfort model allows low minimum operative temperatures. For the cooling energy use, the opposite holds: a lower cooling energy use results if the thermal comfort model allows more days with higher operative temperatures. Evidently, this is only indicative, because the real energy use of the building will depend on the dynamics occurring at the specified time.

The following conclusions can be drawn from Fig. 4:

- ISO7730 shows for both $T_{o p, \min }$ and $T_{o p, \max }$ a gradually increasing curve;

- Although the adaptive ASHRAE55 model is by far the least stringent for $T_{o p, \min }$, with the temperature data of Maastricht, it allows lower maximal operative room temperatures $T_{o p, \max }$ compared to ISO7730. As a result, a building zone will possibly show a higher cooling need for the adaptive ASHRAE55 model than for the ISO7730 model;

- EN15251 shows low temperature limits for $T_{o p, \min }$, but, as already shown in the previous section, allows very high temperatures in the summer situation. This is caused by the adaptive curve being $1^{\circ} \mathrm{C}$ higher than the other adaptive methods.

Again, also using this approach, it must be concluded that the non-adaptive ISO7730 model will not necessarily result in higher energy use.

\subsection{Analysis of the ISO7730 interpolation assumption.}

One of the assumptions in Section 2.5 was the linear interpolation between $10^{\circ} \mathrm{C}$ and $15^{\circ} \mathrm{C}$ for both $T_{o p \text {,min }}$ and $T_{o p \text {,max }}$ of the ISO7730 model. Strictly following the EN15251 standard $T_{o p \text { max }}$ changes at $10^{\circ} \mathrm{C}$ and $T_{o p, \min }$ at $15^{\circ} \mathrm{C}$. Using these temperature limits, the number of days that $T_{o p \text {,max }}$ and $T_{o p \text {,min }}$ are in a certain temperature range changes, which is shown in Table 9.

Table 9

Analysis of the ISO7730 interpolation assumption.

\begin{tabular}{|c|c|c|c|c|c|}
\hline \multicolumn{3}{|l|}{$T_{o p, \min }$} & \multicolumn{3}{|l|}{$T_{o p, \max }$} \\
\hline Range & w interpol & w/o interpol & Range & w interpol & $\mathrm{w} / \mathrm{o}$ interpol \\
\hline$<20^{\circ} \mathrm{C}$ & 209 & 285 & $<24^{\circ} \mathrm{C}$ & 209 & 209 \\
\hline $20.5^{\circ} \mathrm{C}$ & 0 & 0 & $24.5^{\circ} \mathrm{C}$ & 14 & 0 \\
\hline $21^{\circ} \mathrm{C}$ & 14 & 0 & $25^{\circ} \mathrm{C}$ & 15 & 0 \\
\hline $21.5^{\circ} \mathrm{C}$ & 15 & 0 & $25.5^{\circ} \mathrm{C}$ & 25 & 0 \\
\hline $22^{\circ} \mathrm{C}$ & 25 & 0 & $26^{\circ} \mathrm{C}$ & 102 & 156 \\
\hline $22.5^{\circ} \mathrm{C}$ & 22 & 0 & & & \\
\hline $23^{\circ} \mathrm{C}$ & 80 & 80 & & & \\
\hline
\end{tabular}


Table 10

Parameters of the 2-zone building section.

\begin{tabular}{ll}
\hline Building parameters & \\
\hline Heated volume $\left(\mathrm{m}^{3}\right)$ & 128.5 \\
Heated area $\left(\mathrm{m}^{2}\right)$ & 37.8 \\
Transmission area $\left(\mathrm{m}^{2}\right)$ & 10.8 \\
$U$-value external wall $\left(\mathrm{W} / \mathrm{m}^{2} \mathrm{~K}\right)$ & 0.29 \\
$U$-value total $\left(\mathrm{W} / \mathrm{m}^{2} \mathrm{~K}\right)$ & 0.96 \\
Glazing: $U$-value $\left(\mathrm{W} / \mathrm{m}^{2} \mathrm{~K}\right) ; g$-value $(\%)$ & $1.6 ; 40$ \\
Percentage of glazing $(\%)$ & 50 \\
\hline
\end{tabular}

In the case without interpolation, there will be more days with a lower $T_{o p, \min }$ which will lower the required heating energy. $T_{o p, \max }$ has 54 days extra at $26^{\circ} \mathrm{C}$, which will be beneficial to the required cooling energy. Therefore, for ISO7730, the interpolation assumption will result in a higher energy demand, compared to the case without interpolation.

\section{Building zone energy use as a function of the thermal comfort model applied}

To evaluate the effect of the thermal comfort model and the effect of a real warm year on the energy use of an office building, a TRNSYS [17] simulation is run on a typical office building zone.

\subsection{2-Zone building section description}

The 2-zone building section is a cut-out of a typical office building with South and North orientated offices separated by a corridor. The outside wall has a total U-value of $0.29 \mathrm{~W} / \mathrm{m}^{2} \mathrm{~K}$. This is a high level of insulation compared to standard building practice [18]. However, the heat conduction through the opaque envelope parts is small compared to other heat losses and gains. The ceiling is covered with gypsum. The raised floor is $20 \mathrm{~cm}$ high and tiles are made of gypsum related material. The office space is separated from the corridor by a light gypsum wall. The outside window has a thermally insulated aluminium frame and is placed without thermal bridges. The corridor is equipped with a suspended ceiling used for hot and cold water supply, air ducts, electricity and ICT (Fig. 5 and Table 10).

\subsection{Simulation assumptions}

The office zones in this simulation are heated and cooled by means of ideal heat and cold emitters with sufficient power to keep the room continuously at the required temperature. No night setback is used. The set points for heating and cooling are defined by the respectively lower and upper temperature limits as imposed by the different thermal comfort models. Because the set points in the
Table 11

Heating and cooling energy use for the South and North zone (with $Q_{\text {heat }}$ and $Q_{\text {cool }}$ in $\mathrm{kWh} / \mathrm{m}^{2}$ and relative to ISO7730).

\begin{tabular}{|c|c|c|c|c|c|c|}
\hline & \multicolumn{2}{|c|}{ South zone } & \multicolumn{2}{|c|}{ North zone } & \multicolumn{2}{|l|}{ Total } \\
\hline & $Q_{\text {heat }}$ & $Q_{\text {cool }}$ & $Q_{\text {heat }}$ & $Q_{\text {cool }}$ & $Q_{\text {heat }}$ & $Q_{\text {cool }}$ \\
\hline \multirow{2}{*}{ ISO7730 } & 32 & 57 & 40 & 26 & 36 & 42 \\
\hline & $100 \%$ & $100 \%$ & $100 \%$ & $100 \%$ & $100 \%$ & $100 \%$ \\
\hline \multirow[t]{2}{*}{ ASHRAE55 adaptive } & 28 & 62 & 34 & 30 & 31 & 46 \\
\hline & $87 \%$ & $107 \%$ & $85 \%$ & $115 \%$ & $86 \%$ & $110 \%$ \\
\hline \multirow[t]{2}{*}{ ISSO74 } & 40 & 69 & 47 & 34 & 43 & 51 \\
\hline & $122 \%$ & $119 \%$ & $117 \%$ & $132 \%$ & $119 \%$ & $123 \%$ \\
\hline \multirow[t]{2}{*}{ EN15251 adaptive } & 32 & 52 & 40 & 21 & 36 & 36 \\
\hline & $100 \%$ & $91 \%$ & $99 \%$ & $80 \%$ & $100 \%$ & $88 \%$ \\
\hline
\end{tabular}

simulation model are compared with air temperatures, the upper operative temperature limit from the comfort model is decreased with $0.5^{\circ} \mathrm{C}$ and the lower limit is increased with $0.5^{\circ} \mathrm{C}$ to compensate for the difference between air and operative temperature [19]. The office is occupied from Monday to Friday from 8 a.m. till 6 p.m. The occupants have a lunch break during $1 \mathrm{~h}$, but appliances and light remain on during this period. People perform sedentary office activity with a sensible heat output of $90 \mathrm{~W} /$ pers $(40 \%$ convective, $60 \%$ radiative) ([20]; for an air temperature of $22^{\circ} \mathrm{C}$ ). Latent heat is not taken into account for these simulations, because this will not be influenced by the heating or cooling set points, apart from the small temperature dependency of the latent heat output of people. For each person $150 \mathrm{~W}$ of electric power is consumed for appliances such as PC, printer, etc., according to the ASHRAE recommendations [10]. In reality the consumption of PC's might be more than two times higher though [21], so this can be seen as a rather conservative value. Diversity factors are applied: $150 \mathrm{~W} /$ person is the heat gain from 1 PC and monitor [21] with a diversity factor of 0.75 and 1 desk printer with a diversity factor of 0.5 . Lights have an electric power of $10 \mathrm{~W} / \mathrm{m}^{2}$ of which $80 \%$ enters the zone as a radiative heat flux, while $20 \%$ is convective. During the night, a residual electric power of $1 \mathrm{~W} / \mathrm{m}^{2}$ enters the office zone as a pure convective heat flux. Hygienic ventilation is provided at a rate of $36 \mathrm{~m}^{3} / \mathrm{h}$.person during occupation hours and enters the room at a constant temperature of $18^{\circ} \mathrm{C}$.

For this simulation it is explicitly chosen not to use real heating and cooling equipment in the building, since the energy use would largely depend on the applied control strategy. This would hamper the allocation of the differences in energy use to the thermal comfort models applied.

\subsection{Simulation results}

Dependent on the comfort model applied the net heating energy use ranges from $30 \mathrm{kWh} / \mathrm{m}^{2}$ to almost $50 \mathrm{kWh} / \mathrm{m}^{2}$ (Table 11). For

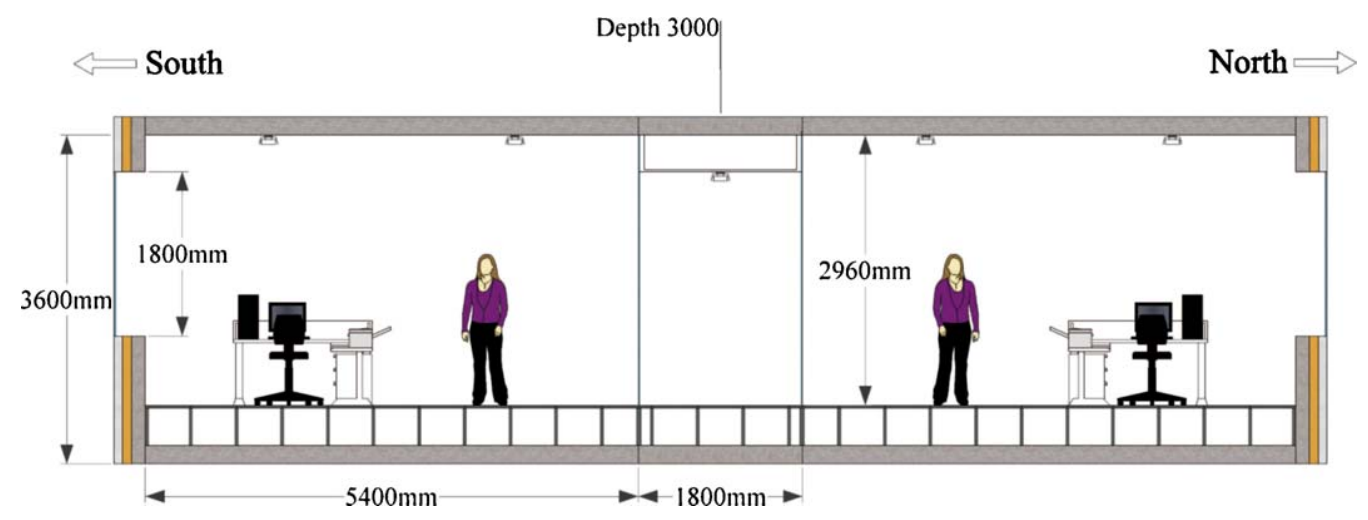

Fig. 5. 2D view of the 2-zone building section. 


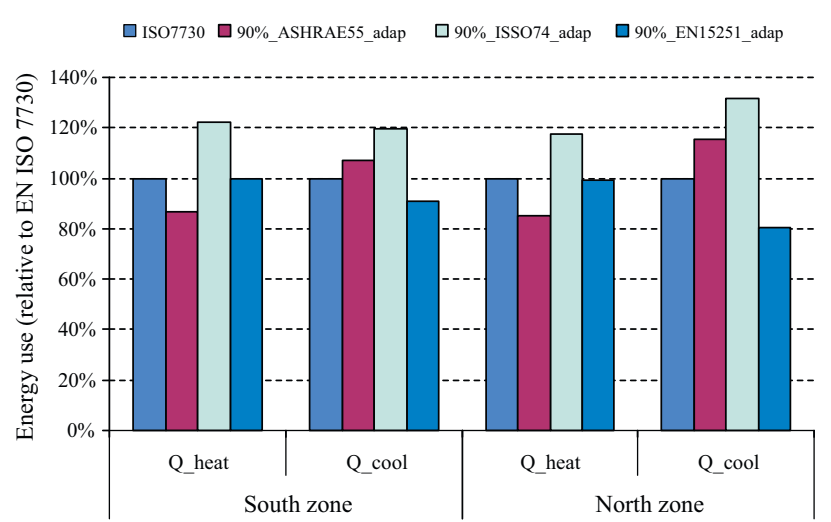

Fig. 6. Required net energy for heating and cooling to keep the zone temperature within the imposed temperature range (relative to the ISO7730 energy need).

cooling, the net energy use range is wider, going from $20 \mathrm{kWh} / \mathrm{m}^{2}$ to $70 \mathrm{kWh} / \mathrm{m}^{2}$. Heating and cooling of the ventilation air is included in the net energy values presented.

Fig. 6 shows the results relative to the energy use with the ISO7730 model applied. It demonstrates that the use of adaptive thermal comfort models does not necessarily result in relevant energy savings. For heating, only the ASHRAE55 model results in a substantially lower energy use. This is hardly surprising, given it is much lower minimum operative temperature compared to the other models. Questions could be raised whether this low winter temperature is still comfortable, compared to e.g. Oseland's [22] conclusions of a minimal winter temperature of a little lower than $20^{\circ} \mathrm{C}$ in office environments, which is equal to the ISO7730 minimum temperature. Also, according to de Dear and Brager's own discussion [13], this comfort model is not applicable when $T_{\text {ref,out }}$ drops below $10^{\circ} \mathrm{C}$.

None of the other adaptive models results in a lower heating energy use, which in fact is not surprising. First of all, adaptive models aim at a different approach of the summer comfort and do not focus on winter criteria. Secondly, all but the adaptive ASHRAE55 model, show higher or equal winter temperatures (for $T_{\text {ref,out }}$ below $10^{\circ} \mathrm{C}$ ). Only the ISSO74 model drops below the ISO7730 limit for $T_{\text {ref,out }}$ lower than $-2{ }^{\circ} \mathrm{C}$. For the Maastricht TRY this happens in only $2.5 \%$ of the days, while $50 \%$ of the days have a reference outdoor temperature between $-2^{\circ} \mathrm{C}$ and $10^{\circ} \mathrm{C}$. Regarding the heating case, it should be noted that a major part of the heating energy $(>3 / 4)$ is required to heat the ventilation air to the specified inlet temperature of $18^{\circ} \mathrm{C}$.

Regarding cooling only the EN15251 model results in a substantially lower energy use, caused by the much higher maximum operative temperatures compared to the other comfort models (see Fig. 2). Both the ASHRAE55 and the ISSO74 model result in a higher energy use. There are few warm days present in the Maastricht TRY, which reduces the potential benefit of these adaptive models, but more important, they impose lower operative temperatures during winter and mid-season period. Because the office building considered requires cooling practically the whole year round, these winter and mid-season limits effect the final result largely. Fig. 7 shows that $90 \%$ (for the South zone) and $83 \%$ (for the North zone) of the cooling energy need is generated during days where $T_{o p, \max }$ as prescribed by ISSO74 is lower than $26^{\circ} \mathrm{C}$, the maximum of ISO7730. Where de Dear and Brager allot 'their' adaptive ASHRAE55 model to the warm and humid climates [13] - making it less applicable to the investigated situation - for the ISSO74 model this is not expected, because this comfort model is explicitly designed for use in moderate climate zones.

Fig. 8(a) demonstrates the distribution of the required cooling energy throughout the year. For the ISO7730 model

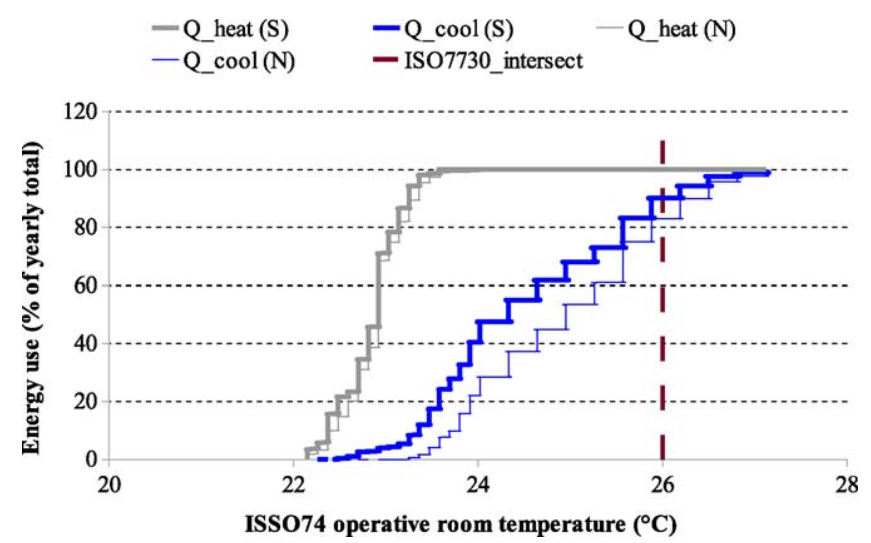

Fig. 7. Cumulative net energy for heating and cooling as a function of the prescribed operative temperature by the ISSO74 comfort model for the North (N) and South (S) zone of the office building.

this is $7 \%$ in Winter (December-February), 26\% in Spring (March-May), 41\% in Summer (June-August) and 27\% during Autumn (September-November). The EN15251 model with equal winter temperatures and higher summer temperatures results in the same absolute value for winter, but lower values for the other seasons. The ASHRAE55 model has a comparable winter value but higher values for the other seasons, while the ISSO74 model shows higher absolute values for all seasons. The largest difference occurs in winter: the required cooling energy more than doubles compared to ISO7730. For the ISSO74 model, a shift in the distribution of the required cooling energy is noticable from summer to winter season: $12 \%$ in Winter, $26 \%$ in Spring, 36\% in Summer and 26\% during Autumn. The low operative winter temperatures raise the winter part to a higher extent than the high allowed operative summer temperatures reduce the summer part.

\subsection{Building zone energy use for the Maastricht year of 2003}

As indicated in Section 3.3, a warm year like 2003 can largely affect the heating and cooling set points determined by the thermal comfort model applied. This, on its turn, will influence the required heating and cooling energy to condition the building. Henze et al. [23] for instance conclude that for an extreme summer, an energy use reduction is observed by applying an adaptive comfort model (EN15251) compared to the non-adaptive ISO7730 model. When the same procedure is applied to the 2-zone office building of Section 4.1 as for the TMY weather data, the results (Table 12) indicate that, compared to the ISO7730 model, the net cooling energy remains higher for the ASHRAE55 and ISSO74 model and is lower for the adaptive EN15251 model. This is the same conclusion as for the TMY of Maastricht, although the differences between ASHRAE55 and ISSO74 on the one hand and ISO7730 on the other hand are smaller.

Table 12

Heating and cooling energy use for the south and north zone (with $Q_{\text {heat }}$ and $Q_{\text {cool }}$ in $\mathrm{kWh} / \mathrm{m}^{2}$ ) for the 2003 weather data of Maastricht.

\begin{tabular}{|c|c|c|c|c|c|c|}
\hline & \multicolumn{2}{|c|}{ South zone } & \multicolumn{2}{|c|}{ North zone } & \multicolumn{2}{|l|}{ Total } \\
\hline & $Q_{\text {heat }}$ & $Q_{\text {cool }}$ & $Q_{\text {heat }}$ & $Q_{\text {cool }}$ & $Q_{\text {heat }}$ & $Q_{\text {cool }}$ \\
\hline \multirow[t]{2}{*}{ ISO7730 } & 26 & 84 & 34 & 41 & 30 & 63 \\
\hline & $100 \%$ & $100 \%$ & $100 \%$ & $100 \%$ & $100 \%$ & $100 \%$ \\
\hline \multirow[t]{2}{*}{ ASHRAE55 adaptive } & 23 & 86 & 28 & 43 & 26 & 65 \\
\hline & $90 \%$ & $103 \%$ & $84 \%$ & $104 \%$ & $86 \%$ & $104 \%$ \\
\hline \multirow[t]{2}{*}{ ISSO74 } & 32 & 93 & 41 & 48 & 36 & 70 \\
\hline & $124 \%$ & $111 \%$ & $120 \%$ & $116 \%$ & $122 \%$ & $112 \%$ \\
\hline \multirow{2}{*}{ EN15251 adaptive } & 26 & 76 & 34 & 34 & 30 & 55 \\
\hline & $100 \%$ & $90 \%$ & $99 \%$ & $81 \%$ & $100 \%$ & $87 \%$ \\
\hline
\end{tabular}




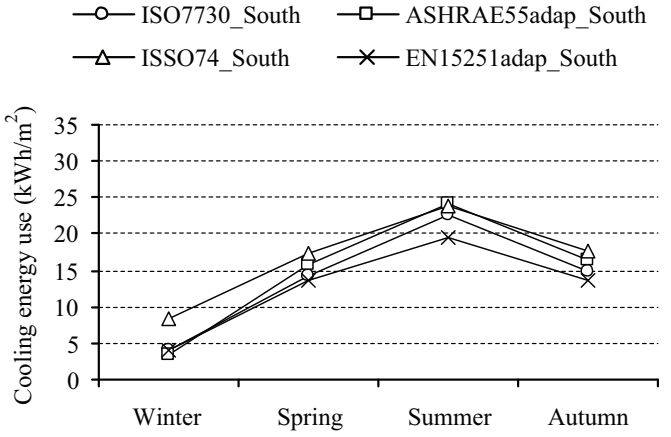

(a) Maastricht TMY
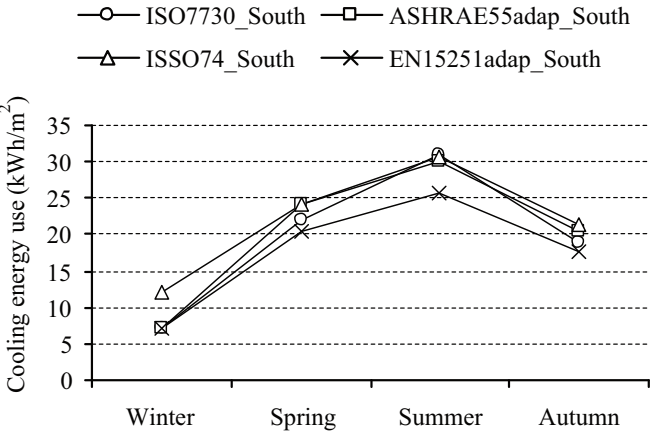

(b) Maastricht year 2003

Fig. 8. Net cooling energy throughout the year for the South zone ((a) : Maastricht TMY; (b) : Maastricht year 2003).

Fig. 8(b) learns that for the warm year of 2003, the adaptive thermal comfort models of ASHRAE55 and ISSO74 are able to lower the net cooling energy use for the summer period compared to the ISO7730 model, but this does not compensate for the higher energy demands for the other seasons. Therefore, the overall net cooling energy use remains higher.

To conclude, although the year 2003 is warmer (see Table 6) than the TMY, the cooling requirements during winter and midseason are still dominant and consequently, the adaptive models of ASHRAE55 and ISSO74 do not result in a lower overall energy use for cooling.

\subsection{Influence of heat gains on energy use}

Sections 3.2 and 4.3 demonstrated that the difference in outcome between the ISO7730 and the adaptive models is primarily determined by the high cooling need of the office building in the winter and mid season period. This raises the question whether this can be lowered. In the current simulation set-up, the internal gains are realistically based on a $10 \mathrm{~m}^{2}$ /pers occupation and heat gain data from ASHRAE [10] and VDI2078 [20]. The electricity consumption of modern desktop stations can be more than two times higher though [21], so the current simulation model is conservative at that point.

People are simulated with a constant sensible heat output of $90 \mathrm{~W}$, as indicated by [20] for a room temperature of $22^{\circ} \mathrm{C}$. Lowering this value to $75 \mathrm{~W} /$ person lowers the net cooling energy use with 5\% and 9\% for the South and North zone respectively. The reduction is equal for all seasons though, so this will not influence the conclusions with regard to the thermal comfort models.

Office appliances are now simulated as a $100 \%$ convective heat source. Bringing the radiant convective split to $50 \%-50 \%$, which is higher than recommended by ASHRAE for all types of office appliances, has a small effect on the simulation results: the net cooling energy use lowers with $2.5 \%$ and $4.5 \%$ for the South and North zone respectively. Again, the reduction is equal for all seasons.

Lighting energy use is also estimated low, with its $10 \mathrm{~W} / \mathrm{m}^{2}$ power consumption. On the other hand, in the simulation model the window surface is $50 \%$ of the total building façade, which is high for modern high quality office buildings. Since the combined internal gains account for $2 / 3$ rd of the total heat gains, influencing the solar gains will not affect the results of the simulation drastically. Simulating the same building with $30 \%$ window surface lowers the overall net cooling energy use in the order of $10 \%$, but the distribution throughout the year remains equal. Therefore, the conclusions regarding the adaptive thermal comfort models remain.

\section{Conclusions}

As described in the literature, both conventional as well as adaptive thermal comfort models are applied to buildings with Thermally Activated Building Systems. In this paper, the effect of the choice of thermal comfort model on the building's energy use, is analysed. This study is performed for a building situated in a moderate climate, such as most of Western and Central Europe. To generalize the conclusions, a building with an ideal heating and cooling system of sufficient power is considered. Otherwise, the system type and the control strategy chosen, would influence the energy use. This would hamper the allocation of the differences in energy use to the thermal comfort models applied. The thermal comfort models limit the operative room temperature to a certain range. The limits of this range are used as the heating and cooling set points for the building's heating and cooling system. The maximum operative temperature $T_{o p \text {, } \max }$ influences the energy use for cooling, while the minimum operative temperature $T_{o p, \min }$ has an impact on the heating energy use.

Different commonly used thermal comfort models are described in terms of outdoor temperature: the non-adaptive and widely used Fanger model (ISO7730) and the adaptive models of ASHRAE55, ISSO74 and EN15251. When applying these models, care should be taken to use the correct outdoor temperature definition: EN15251 and ISSO74 use a running mean temperature (different definition for each model) taking into account the past few days, while the outdoor temperature for the adaptive ASHRAE55 model is the monthly average temperature. The typical ISO7730 model does not consider an outdoor temperature, but defines thermal comfort limits for the 'winter' and 'summer' season. For the calculations in this article, the EN15251 definition is used instead. The high $T_{o p, \max }$ curve for the adaptive EN15251 model is remarkable compared to the ASHRAE55 and ISSO74 thermal comfort models.

Thorough analysis of the different models applied to the moderate climate of Maastricht (The Netherlands), reveals that there are very few periods for which $T_{o p \text {, max }}$ of the ASHRAE55 and the ISSO74 adaptive model is higher than for the non-adaptive ISO7730 model. In order to asses the potential impact on the cooling energy use, the 'ISO7730-Exceeding' Degree Days are introduced, where a comfort model with a $T_{o p, \max }$ being $1^{\circ} \mathrm{C}$ higher compared to the ISO7730 model during the whole year, would yield 365 Kday. The ASHRAE55 model results in 1.4 Kday, while ISSO74 yields 10.1 Kday. The adaptive EN15251 has a higher $T_{o p \text {, } \max }$ starting from a reference outdoor temperature of $10^{\circ} \mathrm{C}$ compared to ISO7730 (46\% of the days are above this limit). This results in a high value of 199.0 Kday. For a moderate, this analysis reveals the low potential of the ASHRAE55 and ISSO74 adaptive thermal comfort models to allow higher indoor temperatures or to lower the cooling energy use due to higher temperature set points. On the contrary, these 
two models show lower winter and midseason maximal operative temperatures compared to the ISO7730 model.

A cooling and heating energy use analysis of a two zone office building with a sufficiently large heating and cooling power and in a moderate thermal climate, reveals that the energy use for cooling is higher when the indoor operative temperature limits are set by the ASHRAE55 and ISSO74 adaptive models compared to the non-adaptive ISO7730 model. This result is caused by the winter regime of the office building zones: the temperature limits are more stringent for cooling in the case of the ASHRAE55 and ISSO74 adaptive models while even during winter time a relevant cooling need remains. The adaptive EN15251 model deviates from these conclusions: with a $T_{o p \text {, max }}$ being higher than ISO7730 starting from an outdoor reference temperature $T_{r m}$ of $10^{\circ} \mathrm{C}$, it results in a cooling energy reduction of $12 \%$. For heating, only the adaptive ASHRAE55 model, which has very low heating set points, results in a lower energy use. But, by definition, this model is not applicable for mean monthly outdoor temperatures below $10^{\circ} \mathrm{C}$, so the conclusions regarding the winter energy use for this model must be treated with caution.

Applying the same procedure to real weather data of exceptionally warm years like 2003, does not change the conclusions. Evidently, in the cooling case, the energy use difference between the non-adaptive ISO7730 and the ASHRAE55 and ISSO74 adaptive models is lowered compared to the Typical Meteorological Year, but still the cooling requirements during winter time are dominant. Therefore, the conclusions hold. Simulating the office zones with lower internal or external gains, does not alter the conclusions either.

Considering the fact that the ASHRAE55 and the ISSO74 adaptive thermal comfort models do not result in energy savings, for a moderate climate and for office buildings with a cooling load throughout the year, it can be concluded that applying these adaptive thermal comfort models does not offer benefits compared to the basic nonadaptive thermal comfort model of ISO7730. The EN15251 model, having the same winter criteria as the ISO7730 model, but considerably less stringent summer criteria, is the only adaptive thermal comfort model resulting in an effective reduction of the cooling energy. This analysis confirms that the criteria of minimum energy use and maximum thermal comfort are conflicting: pressing for a low energy use, means relaxing the thermal comfort requirements. A compromise has to be reached based on people's priorities.

\section{References}

[1] ANSI/ASHRAE Standard 55-2004, Thermal Environmental Conditions for Human Occupancy, American Society of Heating, Refrigeration and Airconditioning Engineers, Inc., 2004.
[2] Comité Européen de Normalisation, EN15251:2007, Indoor Environmental Input Parameters for Design and Assessment of Energy Performance of Buildings Addressing Indoor Air Quality, Thermal Environment, Lighting and Acoustics, 2007.

[3] International Organization for Standardization, ISO7730:2005, Ergonomics of the Thermal Environment - Analytical Determination and Interpretation of Thermal Comfort Using Calculation of the PMV and PPD Indices and Local Thermal Comfort Criteria, 2005.

[4] A. van der Linden, A. Boerstra, A. Raue, S. Kurvers, R. de Dear, Adaptive temperature limits: a new guideline in The Netherlands (a new approach for the assessment of building performance with respect to thermal indoor climate), Energy and Buildings 38 (2006) 8-17.

[5] B. Lehmann, V. Dorer, M. Koschenz, Application range of thermally activated building systems tabs, Energy and Buildings 39 (2007) 593-598.

[6] M. Koschenz, B. Lehmann, Thermoaktive Bauteilsysteme tabs, EMPA Energiesysteme/Haustechnik, Duebendorf (Switzerland), 2000.

[7] J. Pfafferott, S. Herkel, D.E. Kalz, A. Zeuschner, Comparison of low-energy office buildings in summer using different thermal comfort criteria, Energy and Buildings 39 (2007) 750-757.

[8] A. Wagner, E. Gossauer, C. Moosmann, T. Gropp, R. Leonhart, Thermal comfort and workplace occupant satisfaction-results of field studies in German low energy office buildings, Energy and Buildings 39 (2007) 758-769.

[9] B. Olesen, K. Parsons, Introduction to thermal comfort standards and to the proposed new version of EN-ISO7730, Energy and Buildings 34 (2002) 537548.

[10] ASHRAE FUNDAMENTALS, ASHRAE Handbook Series, American Society of Heating, Refrigeration and Air-conditioning Engineers, Atlanta, 2009.

[11] F. Nicol, M. Humphreys, Derivation of the adaptive equations for thermal comfort in free-running buildings in European standard EN15251, Building and Environment 45 (2010) 11-17.

[12] R.J. de Dear, G. Brager, D. Cooper, Developing an Adaptive Model of Thermal Comfort and Preference, FINAL REPORT ASHRAE RP- 884, Technical Report, ASHRAE, 1997.

[13] R.J. de Dear, G.S. Brager, Thermal comfort in naturally ventilated buildings: revisions to ASHRAE Standard 55, Energy and Buildings 34 (2002) 549561.

[14] J. Tödtli, M. Gwerder, B. Lehmann, F. Renggli, V. Dorer, TABS Control, Steuerung und Regelung von thermoaktiven Bauteilsystemen, Faktor Verlag, Zürich, 2009.

[15] J. van Hoof, J.L. Hensen, Quantifying the relevance of adaptive thermal comfort models in moderate thermal climate zones, Building and Environment 42 (2007) 156-170.

[16] Koninklijk Nederlands Meteorologisch Instituut (KNMI), www.knmi.nl, consulted on march, 2008.

[17] SEL-University of Wisconsin-USA and TRANSSOLAR-Stuttgart, TRNSYS 16 , Transient System Simulation Program, 2005.

[18] C. Neumann, S. Herkel, Langzeitmonitoring der Demonstrationsgebäude im Rahmen des Forschungsprogramms EnBau: MONITOR, Technical Report, Fraunhofer ISE, Gruppe Solares Bauen, August 2005.

[19] ISSO Kennisinstituut voor de installatiesector, ISSO-Handboek Installatietechniek (2e versie), ISSO, 2003.

[20] Verein Deutscher Ingenieure, VDI 2078: Berechnung der Kühllast klimatisierter Räume (VDI-Kühllastregeln), VDI-Handbuch Raumlufttechnik, Beuth Verlag $\mathrm{GmbH}$, Berlin, 1996.

[21] M. Duška, J. Lukeš, M. Barták, F. Drkal, J. Hensen, Trend in heat gains from office equipment, in: Proceedings of the 6th International Conference on Indoor Climate of Buildings, Trbské Pleso, SSTP, Bratislava.

[22] N.A. Oseland, Predicted and reported thermal sensation in climate chambers, offices and homes, Energy and Buildings 23 (1995) 105-115.

[23] G.P. Henze, J. Pfafferott, S. Herkel, C. Felsmann, Impact of adaptive comfort criteria and heat waves on optimal building thermal mass control, Energy and Buildings 39 (2007) 221-235. 